\title{
Evaluasi Kesesuaian Lahan untuk Tanaman Jagung di Kabupaten Dompu Berbasis SIG
}

\author{
Sri Apriani puji lestari dan B Harly widayanti \\ Dosen Program Studi Perencanaan Wilayah Dan Kota, Universitas Muhammadiyah Mataram \\ sriaprianipuji@gmail.com
}

\begin{tabular}{l} 
INFO ARTIKEL \\
\hline Riwayat Artikel: \\
Diterima:12-12-2016 \\
Disetujui:02-02-2017
\end{tabular}

\section{Kata Kunci:}

Kesesuaian lahan, Jagung,

SIG

\section{A. LATAR BELAKANG}

Indonesia merupakan Negara yang berhasil dalam mengembangakan berbagai macam jenis tanaman sebagai bahan untuk memenuhi kebutuhan masyarakatnya.Hal ini sejalan dengan potensi lahan yang dimiliki.Keberhasilan suatu jenis tanaman sangat berganung pada kualitas tanaman, lingkungan tempat tumbuh, tempat melakukan budidaya tanam dan

\begin{abstract}
Abstrak: Evaluasi tingkat kesesuain lahan untuk tanaman jagung diperlukan untuk meningkatkan produksi pertanian dan mengoptimalkan penggunaan lahan secara bekesinambungan. Tujuan penelitian ini adalah menyajikan data dan informasi terkait wilayah mana yang cocok untuk pengembanagan tanaman jagung berbasis sistem informasi geografis sehingga bisa dijadikan sebagai bahan pertimbangan dalam perencanaan dan pengembangan wilayah di Kabupaten Dompu. Variabel pengukuran yang digunakan terdiri dari:temperature, ketersediaan air,(curah hujan), ketersediaan oksigen (kondisi drainase tanah), media perakaran(tekstur tanah), bahaya erosi (kelerengan), bahaya banjir (genangan), dan penggunaan lahan. Dari tujuh variabel tersebut menghasilkan tujuh peta yang kemudian di-overlay. Berdasarkan hasil analisa kesesuain lahan tanaman jagung di kabupaten dompu sebesar 30,40\% lahan sangat sesuai, 34,51\% cukup sesuai, 2,15\% sesuai marginal dan 31,94\% tidak sesuai untuk ditanami jagung. Pengembangan budidaya jagung di wilayah Dompu yang paling baik adalah pada wilayah dengan kelas sangat sesuai.
\end{abstract}

Abstract:Evaluation of the level of land suitability for corn crops is needed to increase agricultural production and optimize sustainable land use. The purpose of this study is to present data and information regarding which areas are suitable for developing corn plants based on geographic information systems so that they can be used as consideration in planning and developing areas in Dompu District. The measurement variables used consisted of: temperature, water availability (rainfall), oxygen availability (soil drainage conditions), root media (soil texture), erosion hazard (slope), flood hazard (inundation), and land use. Of the seven variables produced seven maps which were then overlaid. Based on the results of the analysis of land suitability of maize in dompu regency of $30.40 \%$, the land is very suitable, $34.51 \%$ is quite suitable, $2.15 \%$ is suitable marginal and $31.94 \%$ is not suitable for planting corn. The best development of maize cultivation in the Dompu area is in areas with very suitable classes.

pengelolaan yang dilakukan oleh petani.Sehingga memberikan dampat berupa meningkatkan hasil produksi tanaman tersebut.untuk itu dalam rangka pengembangan suatu komoditas tanaman, pertama kali yang harus dilakukan adalah mengetahui persyaratan tumbuh dari komoditas yang akan dikembangkan dan kemudian mengidentifikasi serta menganalisis wilayah mana yang memiliki potensi tempat tumbuh yang sesuai. 
Provinsi Nusa Tenggara Barat merupakan salah satu provinsi di Indonesia yang memiliki kontribusi terbesar di dalam sektor pertanian. Jenis komoditas unggulan di sektor pertanian yang ada di Provinsi Nusa Tenggara Barat antara lain berupa padi dan jagung. Luas wilayah Provinsi Nusa Tenggara Barat NTB 2.015.315 ha yang terdiri dari 2 (dua) pulau besar yaitu pulau Lombok dan pulau sumabawa. Berdasarkan data yang ada, 6,28\% luas lahan di Provinsi Nusa Tenggara Barat dimanfaatkan untuk pertanian jagung. Untuk lebih jelasnya komposisi luas lahan panen jagung masingmasing kabupaten di Provinsi Nusa Tenggara Barat dapat dilihat pada Tabel 1.

Tabel 1

Persentase Luas Lahan Panen Jagung di Provinsi Nusa Tenggara Barat

\begin{tabular}{lccc}
\hline Kabupaten/Kota & $\begin{array}{c}\text { Luas } \\
\text { Wilayah }\end{array}$ & $\begin{array}{c}\text { Luas } \\
\text { Panen } \\
\text { Jagung } \\
\text { (Ha) }\end{array}$ & $\begin{array}{c}\text { Persentase } \\
\text { Luas Lahan } \\
\text { Panen } \\
\text { Jagung (\%) }\end{array}$ \\
\hline Lombok Barat & 105.387 & 3.987 & 3,78 \\
Lombok Tengah & 120.840 & 3.015 & 2,50 \\
Lombok Timur & 160.555 & 15.658 & 9,75 \\
Sumbawa & 664.398 & 43.043 & 6,48 \\
Dompu & 232.460 & 29.512 & 12,70 \\
Bima & 438.940 & 18.695 & 4,26 \\
Sumbawa Barat & 184.902 & 6.235 & 3,37 \\
Lombok Utara & 80.953 & 5.708 & 705 \\
Kota Mataram & 6.130 & - & - \\
Kota Bima & 20.750 & 724 & 3,49 \\
\multicolumn{1}{c}{ Jumlah } & 2.015 .315 & $\mathbf{1 2 6 . 5 7 7}$ & 6,28 \\
\hline \multicolumn{1}{c}{ Sumber: provina }
\end{tabular}

Sumber: provinsi NTB Dalam Angka, 2015

Berdasarakan tabel 1, kabupaten dompu memiliki luas lahan panen jagung terluas dibandingkan dengan lus lahan panen jagung di kabupaten/kota lainnya. Jumlah produksi jagung di Kabupaten Dompu mencapai 190.059 ton pada tahun 2015 dan jumlah produksi ini mengalami peningkatan dibandingkan dengan tahun 2014 dengan jumlah produksi sebanyak 170,132 ton, seperti yang terlihat pada Gambar 1.

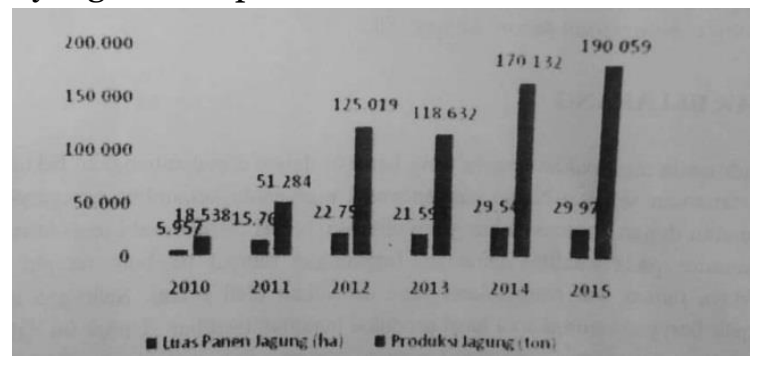

Gambar 1.

Dengan melihat tren peningkatan jumlah produksi dan luas panen jagung di Kabupaten Dompu, maka diperlukan upaya dan strategi untuk mempertahankan dan meningkatkan hasil produksi sehingga bisa menjadi sektor unggulan di Kabupaten Dompu serta memiliki daya saing baik di tingkat provinsi maupun nasional.Salah satu strategi pengembangan wilayah pertanian tanaman pangan dan hortikultura di Kabupaten Dompu dilakukan dengan merencanakan lahan pertanian pangan berkelanjutan dan mengoptimalkan pemanfaatan lahan kering, sehingga perlu adanya perencanaan pertanian yang sesuai dengan kemampuan lahan. Pengolahan lahan yang tidak sesuai dengan kesesuain lahan akan berpengaruh pada hasil produksi yang tidakmaksimal. Evaluasi tingkat kessuain lahan untuk tanaman jagung bertujuan untuk meningkatkan produksi pertanian dan mengoptimalkan penggunaan lahan secara berkesinambungan.Sehingga untuk mencapai hal tersebut perlu dilakukan pengkajian terhadap lahan yang ada agar dapat dimanfaatkan secara optimal.

Untuk mengidentifikasi serta menganalisis wilayah mana yang memiliki potensi tempat tumbuh yang sesuai untuk tanaman jagung diperlukan teknologi berbasis komputer. Sehingga bisa menyajikan data dan informasi terkait wilayah mana yang cocok untuk pengembangan tanaman jagung dana bisa dijadikan sebagai bahan pertimbangan dalam perencanaan dan pengembangan wilayah di Kabupaten Dompu.

\section{B. METODE PENELITIAN}

Penelitian ini menggunakan metode Research And Development, yaitu penelitian yang digunakan untuk menghasilkan produk tertentu, menguji keefektifan produk tersebut (sugiyono,2016: 297). Penelitian ini dilaksanakan di kabupaten Dompu yang terdiri dari 8 (delapan) kecamatan, yaitu: Kecamatan Hu'u, Kecamatan Dompu, Kecamatan Woja, Kecamatan Kempo, Kecamatan Pekat, Kecamatan Manggelewa dan Kecamatan Pajo.

Adapun persyaratan tumbuh tanaman jagung yang dijadikan variabel pada penelitian ini dapat dilihat pada tabel 2.

Tahap cara kerja dalam peneliian ini dimulai dari pengumpulan data, input data, manipulasi dan analisis data menggunakan ArcMAP/GIS. Variabel yang digunakan dalam penelitian ini seluruhnya akan diproses lebih lanjut melalui tahapan interpretasi data, untuk menentukan klasifikasi kesesuain lahan dan penentuan pewilayahan yang sesuai untuk komoditas jagung. Tahap terakhir adalah pemetaan, dimana menggunakan sistem overlay peta/tumpang susun dan pengecekan/survey langsung di lapangan. Proses analisa data spasial sebagian besar dilakukan menggunakan instrument perangkat lunak (software) sistem informasi geografis yaitu ArcMAP/GIS versi 10.1 seperti yang terlihat pada gambar 2.

Tabel 2

Persyaratan Tumbuhan Jagung

\begin{tabular}{llllll}
\hline No & $\begin{array}{c}\text { Kualitas/ } \\
\text { Karakteris } \\
\text { tik Lahan }\end{array}$ & $\begin{array}{c}\text { SI } \\
\text { (sangat } \\
\text { baik) }\end{array}$ & $\begin{array}{c}\text { K2 } \\
\text { (cukup } \\
\text { sesuai) }\end{array}$ & $\begin{array}{c}\text { S3 } \\
\text { (sesuai } \\
\text { margina } \\
\text { 1) }\end{array}$ & $\begin{array}{c}\text { N1 } \\
\text { (tidak } \\
\text { sesuai) }\end{array}$ \\
\hline $1 . \quad$ & $\begin{array}{l}\text { temperature } \\
\text { (t) rata-rata } \\
\text { tahunan }\left({ }^{\circ} \mathrm{c} \text { ) }\right.\end{array}$ & $20-26$ & $26-30$ & $30-32$ & $>32$ \\
ketersediaan \\
air (wa) \\
curah \\
hujan/th \\
(mm)
\end{tabular}




\begin{tabular}{|c|c|c|c|c|c|}
\hline 3. & $\begin{array}{l}\text { ketersediaan } \\
\text { oksigen } \\
\text { (o2), } \\
\text { ditentukan } \\
\text { dari kondisi } \\
\text { drainase } \\
\text { tanah }\end{array}$ & $\begin{array}{l}\text { baik } \\
\text { sampai } \\
\text { dengan } \\
\text { agak ter- } \\
\text { hambat }\end{array}$ & $\begin{array}{l}\text { agak } \\
\text { cepat }\end{array}$ & $\begin{array}{l}\text { Terham- } \\
\text { bat }\end{array}$ & $\begin{array}{l}\text { sangat } \\
\text { terhambat, } \\
\text { cepat }\end{array}$ \\
\hline 4. & $\begin{array}{l}\text { media } \\
\text { perakaran } \\
\text { tekstur } \\
\text { tanah }\end{array}$ & $\begin{array}{l}\text { halus, } \\
\text { agak } \\
\text { halus, } \\
\text { sedang }\end{array}$ & berbutir & $\begin{array}{l}\text { agak } \\
\text { kasar }\end{array}$ & kasar \\
\hline 5. & $\begin{array}{l}\text { bahaya erosi } \\
\text { (eh) lereng } \\
\text { (\%) }\end{array}$ & $>5$ & $5-15$ & $15-25$ & $>25$ \\
\hline 6. & $\begin{array}{l}\text { bahaya } \\
\text { banjir (fh) } \\
\text { genangan }\end{array}$ & $\begin{array}{l}\text { tidak } \\
\text { pernah } \\
\text { terjadi } \\
\text { banjir }\end{array}$ & $\begin{array}{l}\text { ringan } \\
\text { (kurang } \\
\text { dari } 1 \\
\text { bulan) }\end{array}$ & $\begin{array}{l}\text { sedang } \\
(1-3 \\
\text { bulan/ } \\
\text { tahun) }\end{array}$ & $\begin{array}{l}\text { berat (diatas } 3 \\
\text { bulan/tahun) }\end{array}$ \\
\hline 7. & $\begin{array}{l}\text { penggunaan } \\
\text { lahan }\end{array}$ & $\begin{array}{l}\text { sawah/ } \\
\text { lahan } \\
\text { pertanian }\end{array}$ & $\begin{array}{l}\text { Perke- } \\
\text { bunan }\end{array}$ & $\begin{array}{l}\text { semak } \\
\text { belukar, } \\
\text { tanah } \\
\text { terbuka, } \\
\text { dan hutan } \\
\text { lahan } \\
\text { kering } \\
\text { sekunder }\end{array}$ & lainnya \\
\hline
\end{tabular}

Sumber: Djaenuddin Et Al., (2003) dan Muhsoni (2010) yang Dimodifikasi

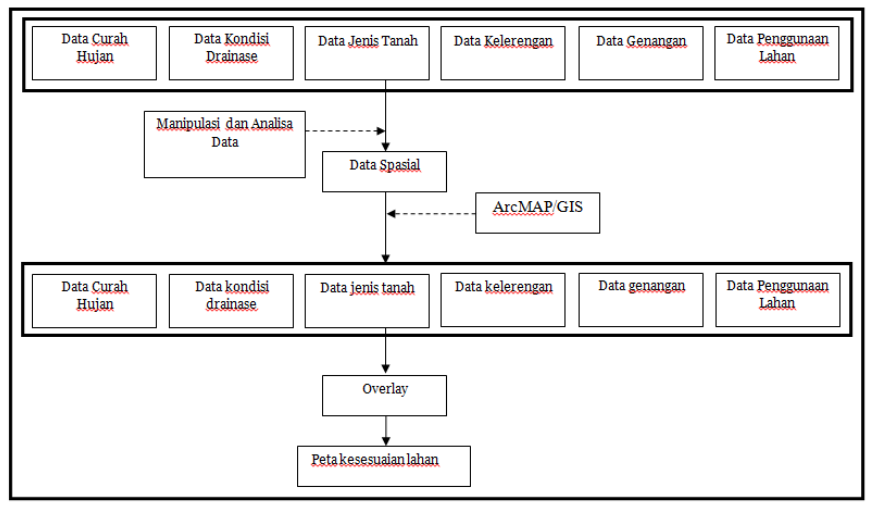

Gambar 2.Alur Pembuatan Peta Kesesuain Lahan Untuk

Tanaman Jagung

\section{HASIL DAN PEMBAHASAN}

\section{Gambaran Umum Kabupaten Dompu}

Kabupaten Dompu memiliki fungsi sebagai salah satu pusat pengembangan kapet Bima untuk wilayah bagian barat. Kabupaten Dompu terletak diantara 117042'118030' Bujur Timur dan 8006'- 9005' Lintang Selatan dengan luas wilayah 232.460 ha dan ketinggian kota berkisar antara 15 - 62 meter di atas permukaan laut. Jenis tanah di Wilayah Dompu meliputi aluvial, kompleks renzina, mediteran coklat, latosol coklat kemerahan, litosol, grumosol, dan regosol.

\section{Analisis Kesesuaian Lahan}

Penilain kelas kesesuaian lahan tanaman jagung disajikan dalam bentuk peta untuk masing-masing kriteria kesesuaian. Berdasarkan parameter kesesuaian lahan menurut Djaenuddin et., (2003) dan muhsoni (2010) maka terdapat tujuh peta. Peta-peta tersebut kemudian di-overlay hingga didapakan peta kesesuain lahan untuk tanaman jagung.

Kabupaten Dompu beriklim tropis, dipengaruhi oeh musim kemerau,dan msin hujan,dimana musinm hujan relatife lebih pendek dibandingkan dengan musim kemerau. Suhu udara berkisar antara $230 \mathrm{C}-340 \mathrm{C}$ pada siang hari dan 200C pada malam hari.sedangkan berdasarkan persyaratan penggunaan lahan jagung,tanaman ini akan dapat tumbuh normal pada suhu $200-300 \mathrm{C}$, sehingga secara temperature kabpatn dompu sangat cocok untuk tanman jagung(Gambar 3).

Untuk menganalisa ketersediaan air digunakan data curah hujan.Curah hujan berpengaruh bagi pertumbuhan tanaman karena bertindak sebagai penyedia air tanaman sesuai dengan kebutuhannya. Sehingga semakin tinggi curah hujan, maka semakin berpengaruh pula terhadap ketersediaan air untuk tanaman jagung. Keadaan curah hujan di Kabupaten Dompu menujukan curah hujan paling tinggi di Kecamatan Dompu mencapai 1.248 mm/tahun dan yang paling rendah di Kecamatan Pekat mencapai 8 $\mathrm{mm} /$ tahun. Tanaman jagung membutuhkan curah hujan relative sedikit, dimana akan tumbuh normal pada curah hujan $250-5000 \mathrm{~mm}$. sehingga dilihat dari data cuah hujan, wilayah Kabupaten Dompu seluruhnya sesuai untuk tanaman jagung seperti yang terlihat pada Tabel 3 .

Tabel 3.

Luas Wilayah berdasarkan Klasifikasi Curah Hujan di Kabupaten Dompu

\begin{tabular}{|c|c|c|c|}
\hline No & $\begin{array}{l}\text { Klasifikasi Curah } \\
\text { Hujan }\end{array}$ & $\begin{array}{l}\text { Luas } \\
\text { (Ha) }\end{array}$ & $\begin{array}{c}\text { Persentase } \\
(\%)\end{array}$ \\
\hline 1. & $\begin{array}{l}\text { Sangat Sesuai (500- } \\
1200 \text { ) }\end{array}$ & 20.707 & 8,91 \\
\hline 2. & $\begin{array}{l}\text { Cukup Sesuai (1.200- } \\
1.600)\end{array}$ & 47.000 & 20,22 \\
\hline 3. & $\begin{array}{l}\text { Sesuai Margina } \\
(>1.600)\end{array}$ & 164.753 & 70,87 \\
\hline & Total & 232.460 & 100,00 \\
\hline
\end{tabular}

Sumber :Hasil Analisis, 2016

Analisis ketersediaan oksigen dilihat kondisi drainase tanah.Secara umum ketersediaan oksigen yang dilihat dari kondisi drainase tanah di Kabupaten Dompu masuk dalam kategori baik seperti yang terlihat pada tabel klasifikasi kesesuian drainase.

Tabel 4.

Klasifikasi Kesesuain Drainase Tanah di Kabupaten Dompu

\begin{tabular}{clcc}
\hline No. & $\begin{array}{l}\text { Klasufikasi } \\
\text { Drainase Tanah }\end{array}$ & $\begin{array}{l}\text { Luas } \\
\text { (Ha) }\end{array}$ & $\begin{array}{c}\text { Persentase } \\
\text { (\%) }\end{array}$ \\
\hline 1. & $\begin{array}{l}\text { NI (Sangat } \\
\text { Terhambat,Cepat) }\end{array}$ & 84.179 & 36,21 \\
2. & $\begin{array}{l}\text { S1 (Baik sampai } \\
\text { dengan agak terlabat) }\end{array}$ & 37.451 & 16,11 \\
3. & S2 (Agak cepat) & 110.829 & 47,68 \\
& $\quad$ Total & 232.460 & 100,00 \\
\hline
\end{tabular}

Sumber : Hasil Analisis, 2016

Jenis tanah di Kabupaten Dompu didiminasi oleh tanah coklat kemerahan dengan peresentase luas lahan sebesar 64,02 \% dan gromosol dengan persentase luas lahan sebesar 28,46 \% dan untuk klasifikasi tekstur tanah dapat dilihat pada Tabel 5 .

Tabel 5

Klasifikasi Tekstur Tanah di Kabupaten Dompu

\begin{tabular}{llcc}
\hline No. & $\begin{array}{l}\text { Klasifikasi Tekstur } \\
\text { Tanah }\end{array}$ & $\begin{array}{l}\text { Luas } \\
\text { (Ha) }\end{array}$ & $\begin{array}{c}\text { persentase } \\
\text { (\%) }\end{array}$ \\
\hline 1. & $\begin{array}{l}\text { S1(alluvial,kompleks } \\
\text { renzina, mediteran } \\
\text { coklat, latosol colta } \\
\text { kemerahan, grumosol) }\end{array}$ & & 98,65 \\
& & \\
\hline
\end{tabular}




\begin{tabular}{cccc}
\hline No. & $\begin{array}{c}\text { Klasifikasi Tekstur } \\
\text { Tanah }\end{array}$ & $\begin{array}{c}\text { Luas } \\
\text { (Ha) }\end{array}$ & $\begin{array}{c}\text { persentase } \\
\text { (\%) }\end{array}$ \\
\hline 2. & N1 (regosol dan litosol) & 3.132 & 1,35 \\
& Total & 232.460 & 100,00 \\
\hline
\end{tabular}

Sumber : hasil analisi 2016

Klasifikasi kelerengan di Kabupaten Dompu terbagi menjadi menjadi empat kelas. Yaitu sangat sesuai mencakup 36,25\% wilayah dengann kemiringan $<5 \%$, cukup sesuai mencakup 46,05\% wilyah dengan kemiringan berkisar $5-15 \%$, sesuai. Marginal mencakup 4,16 \% dengan kemiringan berkisar $15-25 \%$, dan tidak sesuai mencakup 13,55\% wilayah dengan kemiringan $>25 \%$ seperti yang terlihat pada Tabel 6 .

Tabel 6.

Kelerengan Kabupaten Dompu

\begin{tabular}{cccc}
\hline No. & $\begin{array}{c}\text { Klasifikasi } \\
\text { Lereng }\end{array}$ & Luas & $\begin{array}{c}\text { Persentase } \\
\text { (\%) }\end{array}$ \\
\hline 1. & $<5 \%$ & 84.259 & 36,25 \\
2. & $5-15 \%$ & 107.047 & 46,05 \\
3. & $15-25 \%$ & 9.662 & 4,16 \\
4. & $>25 \%$ & 31.492 & 13,55 \\
& Total & 232.460 & 100,00 \\
\hline
\end{tabular}

Sumber: Hasil Analisis 2016

Daerah rawan banjir di Kabupaen Dompu terdapat di Kecamaan Dompu dan Woja (RTRW Kabupaten Dompu 2011 - 2031).Berdasarkan data potensi banjir dan aliran DAS maka diporeh hasil klasifikasi daerah rawan banjir seperti yang terlihat pada Tabel 7 .

Tabel 7.

Darah Rawan Banjir Kabupatem Dompu

\begin{tabular}{clcc}
\hline No. & $\begin{array}{l}\text { Klasifikasi } \\
\text { Bahaya } \\
\text { Banjir }\end{array}$ & Luas & $\begin{array}{c}\text { Persentase } \\
\text { (\%) }\end{array}$ \\
\hline 1. & $\begin{array}{l}\text { S1 (tidak } \\
\text { pernah banjir) }\end{array}$ & $45 \cdot 520,78$ & 19,58 \\
2. & $\begin{array}{l}\text { S2 (banjir } \\
\text { ringan) }\end{array}$ & $186.430,96$ & 80,20 \\
$3 . \quad \begin{array}{l}\text { N1 (banjir } \\
\text { berat) } \\
\text { Total }\end{array}$ & 508,26 & 0,22 \\
& 232.460 & 100,00 \\
\hline
\end{tabular}

Sumber: Hasil Analisis 2016

Kabupaten Dompu memiliki beberapa peruntukan lahan seperti permukiman, pertanian lahan kering, pertanian lahan campuran, sawah, hutan, tambak, rawa, savanna, semak belukar, dan tanah terbuka. Pertanian merupakan salah satu eruntukan lahan yang menjadi sektor andalan, ha ini terbukti dari hanpir setengah pendapatan daerah berasal dari sektor tersebut (RTRW Kabupaten Dompu 2011-2031). Klasifikasi kesesuaian lahan penggunaan lahan dapa dilihat pada Tabel 8 .

Tabel 8.

Klasifikasi Penggunaan Lahan Kabupaten Dompu

\begin{tabular}{clcc}
\multicolumn{4}{c}{ Klasifikasi Penggunaan Lahan Kabupaten Dompu } \\
\hline No. & $\begin{array}{c}\text { Klasifikasi } \\
\text { Bahaya Banjir }\end{array}$ & Luas & $\begin{array}{c}\text { Peresentase } \\
\text { (\%) }\end{array}$ \\
\hline 1. & S1 (sawah/tanah & $36.849,88$ & 15,85 \\
& pertanian) & & \\
2. & S2 (perkebunan) & $6.379,537$ & 2,74 \\
3. & S3 (semak belukar, & 120.698 & 51,92 \\
& tanah terbuka, dan & & \\
& hutan lahan kering & & \\
& sekunder) & & \\
4. & N1 (lainnya) & $68.532,63$ & 29,48 \\
& $\quad$ Total & 232.460 & 100,00 \\
\hline
\end{tabular}

\section{Evaluasi Kesesuain Lahan Tanaman Jagung}

Evaluasi kesesuain lahan untuk tanaman jagung di Kabupaten Dompu menggunakan sistem overlay peta. Seluruh data yang sudah diinterpretasikan dalam bentuk peta kemudian dilakukan tumpang tindih/overlay peta, dimana dengan mengklasifikasikan dari masing-masing variabel yang digunakan. Berdasarkan hasl overlay peta, luas lahan yang sangat sesuai 30,40\% atau 70.664,58 Ha, luas lahan cukup sesuai $34,51 \%$ atau 80.213,67 Ha, luas lahan sesuai marginal hanya $2,15 \%$ atau $5.001,80 \mathrm{Ha}$, sedangkan luas lahan tidak sesuai 32,94\% atau 76.579,93 Ha. Untuk lebih jelasnya dapat dilihat pada Gambar 10.

\section{SIMPULAN DAN SARAN}

Kesimpulan dari hasil analisa kesesuain kahan tanaman jagung di Kabuaten Dompu sebesar 30,40\% lahan sangat sesuai, 34,51\% cukup sesuai, 2,15\% sesuai marginal dan 31,94\% tidak sesuai untuk ditanam jagung. Pengembangan budidaya jagung di wilayah Dompu yang paling baik adalah pada wilayah dengan kelas sangat sesuai.

Dan saranya yaitu perlu adanya penelitian lanjutan untuk penentuan kesesuain lahan untuk tanaman jagung di Kabupaten Dompu, karena pada penelitian ini tidak menggunakan variabel retensi hara, toksisitas dan sodositas yang memerlukan uji laboratorium.

\section{DAFTAR RUJUKAN}

[1] Djaenudin, D., Marwan H., Subagwo H., dan A. Hidayat. 2003. Petunjuk Teknik untuk Komoditas Pertanian. Edisi Pertama Tahun 2003, ISBN 979 9474 - 25 - 6. Balai Penelitian Tanah, Pusat Penelitian dan Pengembangan Tanah dan Agroklimat, Bogor, Indonesia

[2] Muhsoni, Farid Firman. 2010. Kesesuain Lahan Untuk Tanaman Jagung di Madura dengan Menggunakan Pengindraan Jauh dan Sistem Informasi Geografis. Jurnal EMBRY. Volume 7 Nomor 1.

[3] Sugiyono. 2016 . Metode Penelitian Kuantitatif, Kualitatif dan $R \& D$. Bandung: Alfabeta

[4] Kabupaten Dompu Dalam Angka 2015. Kantor Badan Pusat Statistic Kabupaten Dompu, 2015.

[5] Provinsi NTB Dalam Angka 2015 . Kantor Badan Pusat StatistiK Provinsi NTB, 2015 